\title{
Penerapan Asuhan Keperawatan Jiwa Dengan Masalah Kecemasan Pada Penderita Gatritis: Studi Kasus
}

\author{
MARDHIANTI \\ mardhiantidhian27@gmail.com
}

\section{BAB I}

PENDAHULUAN

\subsection{Latar Belakang}

Kasus gastritis bukanlah hal yang baru di tahun ini, karena gastritis menyerang orang dewasa maupun anak-anak bahkan juga lansia. Masyarakat Indonesia banyak yang menganggap penyakit gastritis bukanlah sesuatu hal yang serius, sehingga dianggap tidak memerlukan penanganan dengan segera. Sehingga pada gastritis lanjut beresiko menimbulkan kanker, dan juga mengakibatkan pengikisan lambung. Gastritis merupakan gangguan system pencernaan yang biasa disebut (maag). Peradangan yang terjadi pada lambung individu atau inflamasi yang terjadi pada mukosa lambung, yang dikenal di masyarakat sebagai pengertian gastritis (Nurjannah, 2018).

Pada usia lansia, lapisan mukosa lambung akan mengalami penipisan dan melemah, kondisi inilah yang menyebabkan gastritis lebih sering terjadi pada lansia dibandingkan orang yang berusia muda, lebih parah dan beragam. Lansia dengan beberapa kondisi kronis memiliki resiko lebih tinggi untuk mengalami penyakit gastritis, peningkatan berat badan yang sering terjadi pada lansia juga menjadi salah satu faktor lemak yang menumpuk diperut dapat menekan lambung. Gangguan ini tidak hanya di Indonesia bahkan insiden ini terjadi di dunia dari semua kalangan usia, hal ini disebabkan karena beberapa faktor. Antara lain: pengaruh obat-obatan, jenis kelamin, jenis makanan, stress, usia, dan penyebab utama adalah pola makan yang tidak teratur (Nurjannah, 2018)

Kecemasan merupakan suatu respon psikologis maupun fisiologis individu terhadap suatu keadaan yang tidak menyenangkan, atau reaksi atas situasi yang dianggap mengancam( Hulu \& Pardede, 2016) 
Ansietas atau kecemasan merupakan perasaan takut atau ketakutan yang tidak dapat dijelaskan dan merupakan respon stimulus internal dan eksternal yang memiliki tanda dan gejala perilaku,afektif, kognitif dan fisik. Ansietas merupakan suatu respons emosonal sebagai antisipasi terhadap bahaya ( Towsend, 2018)

Keputusasaan merupakan status emosional yang berkepanjangan dan bersifat subyektif yang muncul saat individu tidak melihat adanya alternatif lain atau pilihan pribadi untuk mengatasi masalah yang muncul atau untuk mencapai apa yang diiginkan serta tidak dapat mengerahkan energinya untuk mencapai tujuan yang ditetapkan.

Keputusasaan merupakan keadaan subjektif seorang individu yang melihat keterbatasan atau tidak ada alternatif atau pilihan pribadi yang tersedia dan tidak dapat memobilisasi energy yang dimilikinya Keputusasaan berkaitan dengan kehilangan harapan, ketidakmampuan, keraguan, duka cita, apati, kesedihan, depresi, dan bunuh diri. Sedangkan menurut, mengemukakan bahwa keputusasaan merupakan kondisi yang dapat menguras energi. (NANDA, 2005)

\subsection{Rumusan masalah}

Berdasakan uraian latar belakang maka penulis membuat rumusan masalah sebagai berikut: Asuhan Keperawatan Pada Ny.R dengan kecemasan

\subsection{Tujuan}

\subsubsection{Tujuan Umum}

Untuk memberikan asuhan keperawatan Pada Ny R dengan masalah kecemasan

\subsubsection{Tujuan Khusus}

1. Mahasiwa mampu melakukan Pengkajian pada Ny R Dengan masalah kecemasan

2. Mahasiswa mampu menegakan diagnosa pada Ny R Dengan masalah kecemasan

3. Mahasiswa mampu membuat intervensi pada Ny R Dengan masalah kecemasan

4. Mahasiswa mampu melakukan implementasi pada Ny R Dengan masalah kecemasan

5. Mahasiwa mampu membuat evaluasi pada Ny R Dengan masalah kecemasan 


\section{BAB 2}

\section{TINJAUAN PUSTAKA}

\subsection{Konsep Gastritis}

\subsubsection{Definisi}

Gastritis adalah inflamasi dari mukosa lambung Gastritis adalah segala radang mukosa lambung, Gastritis merupakan keadaan peradangan atau pendarahan pada mukosa lambung yang dapat bersifat akut, kronis, difusi atau local Gastritis merupakan inflamasi pada dinding gaster terutama pada lapisan mukosa gaster Gastritis merupakan peradangan lokal atau penyebaran pada mukosa lambung dan berkembang di penuhi bakteri.

Gastritis (penyakit maag) adalah penyakit yang disebabkan oleh adanya asam lambung yang berlebih atau meningkatnya asam lambung sehingga mengakibatkan imflamasi atau peradangan dari mukosa lambung seperti teriris atau nyeri pada ulu hati. Gejala yang terjadi yaitu perut terasa perih dan mulas.

Ada dua jenis penyakit gastritis yaitu:

1. Gastritis Akut Gastritis akut adalah suatu peradangan permukaan mukosa lambung yang akut. Gatritis Akut paling sering diakibatkan oleh kesalahan diit, mis. makan terlalu banyak, terlalu cepat, makan makanan yang terlalu banyak bumbu atau makanan yang terinfeksi. Penyebab lain termasuk alcohol, aspirin, refluks empedu atau terapi radiasi.

2. Gastritis Kronis Gastritis kronik adalah Suatu peradangan bagian permukaan mukosa lambung yang menahun yang disebabkan oleh ulkus lambung jinak maupun ganas atau bakteri Helicobacter pylori. Bakteri ini berkoloni pada tempat dengan asam lambung yang pekat.

\section{Etiologi}

Penyebab dari Gastritis dapat dibedakan sesuai dengan klasifikasinya sebagai berikut 1. Gastritis Akut Banyak faktor yang menyebabkan gastritis akut seperti: Obat-obatan seperti obat anti inflamasi nonsteroid, silfonamide merupakan obat yang bersifat mengiritasi mukosa lambung. Minuman beralkohol Infeksi bakteri seperti H. pylori, H. heilmanii, streptococci Infeksi virus oleh sitomegalovirus Infeksi jamur seperti candidiasis, 
histoplosmosis, phycomycosis Stress fisik yang disebabkan oleh luka bakar, trauma, pembedahan. Makanan dan minuman yang bersifat iritan. Makanan berbumbu dan minuman dengan kandungan kafein dan alkohol merupakan salah satu penyebab iritasi mukosa lambung.

2. Gastritis Kronik Penyebab pasti dari gastritis kronik belum diketahui, tapi ada dua predisposisi penting yang bisa meningkatkan kejadian gastritis kronik, yaitu infeksi dan non-infeksi Gastritis infeksi Beberapa agen infeksi bisa masuk ke mukosa lambung dan memberikan manifestasi peradangan kronik. Beberapa agen yang diidentifikasi meliputi hal-hal berikut.

a) H. Pylori. Beberapa peneliti menyebutkan bakteri itu merupakan penyebab utama dari gastritis kronik

b) Helicobacter heilmanii, Mycobacteriosis, dan Syphilis

c) Infeksi parasit

d) Infeksi virus (Gastritis non-infeksi

e) Gastropai akbiat kimia, dihubungkan dengan kondisi refluks garam empedu kronis dan kontak dengan OAINS atau aspirin

f) Gastropati uremik, terjadi pada gagal ginjal kronik yang menyebabkan ureum terlalu banyak beredar pada mukosa lambung (Wehbi, 2008).

\section{Patofisiologi}

1. Gastritis Akut. Zat iritasi yang masuk ke dalam lambung akan mengiitasi mukosa lambung. Jika mukosa lambung teriritasi ada 2 hal yang akan terjadi :

a) Karena terjadi iritasi mukosa lambung sebagai kompensasi lambung. Lambung akan meningkat sekresi mukosa yang berupa $\mathrm{HCO} 3$, di lambung $\mathrm{HCO} 3$ akan berikatan dengan NaCL sehingga menghasilkan HCI dan NaCO3.Hasil dari penyawaan tersebut akan meningkatkan asam lambung . Jika asam lambung meningkat maka akan meningkatkan mual muntah, maka akan terjadi gangguan nutrisi cairan \& elektrolit. 
b) Iritasi mukosa lambung akan menyebabkan mukosa inflamasi, jika mukus yang dihasilkan dapat melindungi mukosa lambung dari kerusakan HCL maka akan terjadi hemostatis dan akhirnya akan terjadi penyembuhan tetapi jika mukus gagal melindungi mukosa lambung maka akan terjadi erosi pada mukosa lambung. Jika erosi ini terjadi dan sampai pada lapisan pembuluh darah maka akan terjadi perdarahan yang akan menyebabkan nyeri dan hypovolemik

\section{Gastritis Kronik.}

Gastritis kronik disebabkan oleh gastritis akut yang berulang sehingga terjadi iritasi mukosa lambung yang berulang-ulang dan terjadi penyembuhan yang tidak sempurna akibatnya akan terjadi atrhopi kelenjar epitel dan hilangnya sel pariental dan sel chief. Karena sel pariental dan sel chief hilang maka produksi HCL. Pepsin dan fungsi intinsik lainnya akan menurun dan dinding lambung juga menjadi tipis serta mukosanya rata, Gastritis itu bisa sembuh dan juga bisa terjadi perdarahan serta formasi ulser.

D. Manifestasi Klinik

1. Gastritis Akut yaitu Anorexia, mual, muntah, nyeri epigastrium, perdarahan saluran cerna pada hematemesis melena, tanda lebih lanjut yaitu anemia

2. Gastritis Kronik, Kebanyakan klien tidak mempunyai keluhan, hanya sebagian kecil mengeluh nyeri ulu hati anorexia, nausea, dan keluhan anemia dan pemeriksaan fisik tidak di jumpai kelainan.

E. Komplikasi

1. Komplikasi yang timbul pada Gastritis Akut:

a) Perdarahan saluran cerna bagian atas, yang merupakan kedaruratan medis, terkadang perdarahan yang terjadi cukup banyak sehingga dapat menyebabkan kematian.

b) Ulkus, jika prosesnya hebat

c) Gangguan cairan dan elektrolit pada kondisi muntah hebat. 
2. Komplikasi yang timbul Gastritis Kronik, yaitu gangguan penyerapan vitamin B 12 akibat kurang pencerapan, B 12 menyebabkan anemia pernesiosa, penyerapan besi terganggu dan penyempitan daerah antrum pylorus.

H. Potensial komplikasi
a) terjadinya pendarahan
b) syok
c) perforasi
d) peradangan selaput perut
e) kanker lambung

I. penatalaksanaan
a) Berikan diet tinggi kalori sesuai toleransi
b) Berikan terapi antasida dan antibiotik
c) Berikan agen penyekat kalsium,procardia,isordil
d) Berikan analgesik jenis cair topikal

\subsection{Konsep Ansietas}

\subsubsection{Defenisi Ansietas}

Ansietas adalah perasaan was-was, Khawatir, takut yang tidak jelas atau tidak nyaman seakan-akan terjadi sesuatu yang mengancam. Ansietas adalah perasaan yang tidak nyaman atau ketakutan yang tidak terlalu jelas disertai respon otonom, perasaan takut yang disebabkan oleh antisipasi terhadap bahaya hal ini merupakan isyaratkewaspadaan yang memperingati individu akan adanya bahaya dan memampukan individu untuk bertindak menghadapi ancaman (Keliat, A, B 2019).

Ansietas di definisikan sebagai gangguan kejiwaan yang paling umum dengan gejala kekhawatiran yang berlebihan, hiperaousal, serta kekuatan yang kontra produktif dan melemahkan meskipun kurang terlihat seperti skizofrenia, depresi atau gangguan biopolar, ansietas bisa sama-sama melumpuhkan (Azzahra, F., Oktarlina, R. Z., \& Hutasoit, H. B. K. 2020). 
Penulis menyebutkan bahwa ansietas Ansietas adalah perasaan tidak senang yang khas yang diakibatkan oleh dugaan akan bahaya atau frustrasi yang mengancam yang akan membahayakan rasa aman, keseimbangan, atau kehidupan seseorang individu atau kelompok biososialnya.

\subsubsection{Etiology}

Meski penyebab ansietas belum sepenuhnya diketahui, namun gangguan keseimbangan neurotransmitter dalam otak dapat menimbulkan ansietas pada diri seseorang. Faktor genetik juga merupakan faktor yang dapat juga menimbulkan gangguan ini, ansietas terjadi ketika seseorang mengalami kesulitan menghadapi situa si, masalah dan tujuan hidup Setiap individu menghadapi stress dengan cara berbeda-beda, seseorang dapat tumbuh dalam situasi yang dapa menimbulka 
stress berat pada orang lain adapun faktor-faktornya yang mempengaruhi ansietas adalah :

1. Faktor predisposisi

Berbagai teori yang dikembangkan untuk menjelaskan penyebab ansietas adalah:

a) Teori psikionalitik

Ansietas merupakan konflik emosional antara dua elemen yaitu ide, ego dan super ego. Ide melambangkan dorongan insting, ego digambarkan sebagai mediator antara ide dan super ego mencerminkan hati nurani seseorang dan dikendalikan oleh norma-norma budaya seseorang, ansietas berfungsi untuk memperingatkan ego tenang suatu budaya yang perlu segera diatasi.

b) Teori interpersonal

Ansietas terjadi dari ketakutan akan penolakan interpersonal berhubungan juga dengan trauma masa perkembangan seperti kehilangan, perpisahan. Individu dengan harga diri rendah biasanya sangat mengalami ansietas berat.

c) Teori perilaku

Ansietas merupakan produk frustasi yaitu segala sesuatu yang yang menggangu kemampuan seseorang untuk mencapai tujuan yang diharapkan.

d) Kajian biologis

Kajian biologis menunjukan bahwa otak mengandung reseptor khusus untuk benzodiazepin, obat-obatan yang meningkatan neuroregulator yang berperan penting dalam mekanisme biologis yang berhubungan dengan ansietas (Stuart, Keliat, dan Pasaribu 2016).

e) Faktor presipitasi

Bersumber dari eksternal dan internal seperti :

1. Ancaman terhadap integritas fisik meliputi ketidakmampuan fisiologis atau menurunnya kemampuan melaksanakan fungsi kehidpan sehari-hari (Stuart, Keliat, dan Pasaribu 2016). 
2. Ancaman terhadap sistem diri dapat membahayakan identitas harga diri dan integritas fungsi sosial (Stuart, Keliat, dan Pasaribu 2016).

f) Perilaku

Ansietas dapat diekspresikan langsung melalui perubahan fisiologis dan perilaku secara tidak langsung timbulnya gejala atau mekanisme koping dalam meningkat sejalan dengan peningkatan ansietas

\subsubsection{Tingkat Ansietas}

1. Ansietas Ringan

Ansietas ringan berhubungan dengan ketengan akan peristiwa kehidupan sehari-hari. Pada tingkat ini laangan persepsi melebar dan individu terdorong untuk belajar yang akan menghasilkan pertumbuhan kreatifitas.

\section{a. Respon fisiologis}

1. Sesekali napas pendek

2. Nadi dan tekanan darah naik

3. Gejala ringan pada lambung

4. Muka berkerut dan bibir bergetar

b. Respon kognitif

1. Lapang persepsi melebar

2. Mampu menerima rangsangan yang kompleks

3. Konsentrasi pada maslah

4. Menejlaskan masalah secara efektif

c. Respon perilaku dan emosi

1. Tidak dapat duduk tenang

2. Tremor halus pada tangan

3. Suara kadang-kadang meninggi

2. Ansietas sedang

Pada tingkat ini lapangan persepsi terhadap lingkugan menurun. Individu lebih memfokuskan hal-hal penting dan mengenyampingkan hal-hal lain a. Respon fisiologis 
1. Nadi (ekstra systole) dan tekanan darah naik

2. Mulut kering

3. Anorexia

4. Diare/konstipasi

5. Gelisah

b. Respon kognitif

1. Lapang persepsi menyempit

2. Rangsang luar tidak mampu diterima

3. Berfokus pada apa yang menjadi perhatian

c. Respon perilaku dan emosi

1. Gerakan tersentak-sentak (meremas tangan)

2. Bicara banyak dan lebih cepat

3. Susah tidur

4. Perasaan tidak aman

3. Ansietas berat

Pada ansietas berat lapangan persepsi menjadi sangat sempit, individu cenderung memikirkan hal yang kecil saja dan mengabaikan hal lain,individu tidak mampu lagi berpikir realistis dan membutuhkan pengarahan untuk memusatkan perhatian pada area lain (Pardede, J. A., Sitepu, S. F. A., \& Saragih, M. (2018) :

a. Respon fisiologi

1. Sering nafas pendek Nadi dan tekanan darah naik

2. Berkeringat dan sakit kepala

3. Penglihatan kabur

4. Ketegangan

b. Respon kognif

1. Lapang persepsi sangat sempit

2. Tidak mampu menyelesaikan masalah

c. Respon perilaku dan emosi

d. Perasaan ancam meningkat 
1. verbialisasi cepat

e. Blocking

\subsubsection{Mekanisme Koping}

Ketika pasien mengalami ansietas, individu menggunakan bermacam-macam mekanisme koping untuk mencoba mengatasinya. Dalam bentuk ringan ansietas bentuk ringan ansietas dapat di atasi dengan menangis, tertawa, tidur, olahraga atau merokok Pardede, J. A., Simanjuntak, G. V., \& Laia, R. (2020). Bila terjadi ansietas berat sampai panik akan terjadi ketidakmampuan mengatasi ansietas secara konstruktif merupakan penyebab utama perilaku yang patologis, individu akan menggunakan energy yang lebih besar untuk dapat mengatasi ancaman tersebut.

Mekanisme koping untuk mengatasi ansietas adalah :

a. Reaksi yang berorientasi pada tugas (task oriented reaction) Merupakan pemecahan masalah secara sadar yang digunakan untuk menanggulangi ancaman stressor yang ada secara realistis yaitu:

1. Perilaku menyerang (Agresif) Biasanya digunakan individu untuk mengatasi rintangan agar memenuhi kebutuhan.

2. Perilaku menarik diri Digunakan untuk menghilangkan sumber ancaman baik secara fisik maupun psikologis.

3. Perilaku kompromi Digunakan untuk merubah tujuan yang akan dilakukan atau mengorbankan kebutuhan personal untuk mencapai tujuan.

b. Mekanisme pertahanan ego (Ego oriented reaction) Mekanisme ini membantu mengatasi ansietas ringan dan sedang yang digunakan untuk melindungi diri dan dilakukan secara sadar untuk mempertahankan keseimbangan. Mekanisme pertahanan ego:

1. Disosiasi adalah pemisahan dari proses mental atau perilaku dari kesadaran atau identitasnya. 
2. Identifikasi (identification) adalah proses dimana seseorang untuk menjadi yang ia kagumi berupaya dengan mengambil/meniru pikiranpikiran, perilaku dan selera orang tersebut.

3. Intelektualisasi (intellectualization) adalah penggunaan logika dan alasan yang berlebihan untuk menghindari pengalaman yang mengganggu perasaannya.

4. Introjeksin (introjection) adalah suatu jenis identifikasi yang dimana seseorang mengambil dan melebur nilai-nilai dan kualitas seseorang atau suatu kelompok kedalam struktur egonya sendiri, berupa hati nurani, contohnya rasa benci atau kecewa terhadap kematian orang yang dicintai, dialihkan dengan cara menyalahkan diri sendiri.

5. Kompensasi adalah proses dimana seseorang memperbaiki penurunan citra diri dengan secara tegas menonjolkan keistimewaan/kelebihan yang dimilikinya. Penyangkalan (Denial) adalah menyatakan ketidaksetujuan terhadap realitas dengan mengingkari realitas tersebut. Mekanisme pertahanan ini adalah penting, sederhana, primitif.

6. Pemindahan (displacement) adalah pengalihan emosi yang semula ditujukan pada seseorang/benda kepada orang lain/benda lain yang biasanya netral atau kurang mengancam dirinya.

7. Isolasi adalah pemisahan unsur emosional dari suatu pikiran yang menggangu dapat bersifat sementara atau berjangka lama.

8. Proyeksi adalah pengalihan buah pikiran atau impuls pada diri sendiri kepada orang lain terutama keinginan, perasaan emosional dan motivasi yang tidak dapat ditoleransi.

9. Rasionalisasi adalah mengemukakan penjelasan yang tampak logis dan dapat diterima masyarakat untuk membenarkan perasaan perilaku dan motif yang tidak dapat diterima.

10. Reaksi formasi adalah pengembangan sikap dan pola perilaku yang ia sadari yang bertentangan dengan apa yang sebenarnya ia rasakan atau ingin dilakukan. 
11. Regresi adalah kemunduran akibat stress terhadap perilaku dan merupakan ciri khas dari suatu taraf perkembangan yang lebih dini.

12. Represi adalah pengenyampingkan secara tidak sadar tentangtentang pikiran, ingatan yang menyakitkan atau bertentangan ,dari kesadaran seseorang merupakan pertahanan ego yang primer yang cenderung diperkuat oleh mekanisme lain. 


\section{BAB 3}

TINJAUAN KASUS

\subsection{PENGKAJIAN KEPERAWATAN}

\begin{tabular}{|l|l|}
\hline Nama : Ny R & Kondisi saat MRS: Pasien mengatakan \\
Usia : 45 tahun & bahwasannya mengeluh nyeri dan mual muntah serta \\
Tahun no reg : - & perut kembung dan terkadang bisa tidak sadar. \\
Ruangan : - & Kondisi saat ini : \\
Tgl masuk rs: - & $\begin{array}{l}\text { Ny. R mengeluh Penyakit gastritisnya kambuh dikarenakan } \\
\text { Tgl pengkajian : } 20 \text { oktober } 2021 \\
\text { Alamat : Tegal Rejo Medan perjuangan }\end{array}$ \\
& kecelakaan . \\
& \\
& \\
\hline
\end{tabular}


3.1.1 FAKTOR PREDISPOSISI DAN FAKTOR PRESIPITASI

\begin{tabular}{|c|c|c|c|c|}
\hline \multirow[t]{2}{*}{ Faktor predisposisi } & \multicolumn{3}{|l|}{ Faktor presipitasi } & \multirow[t]{2}{*}{ STRESSOR } \\
\hline & Nature & Origin & $\begin{array}{l}\text { Number \& } \\
\text { Timing }\end{array}$ & \\
\hline 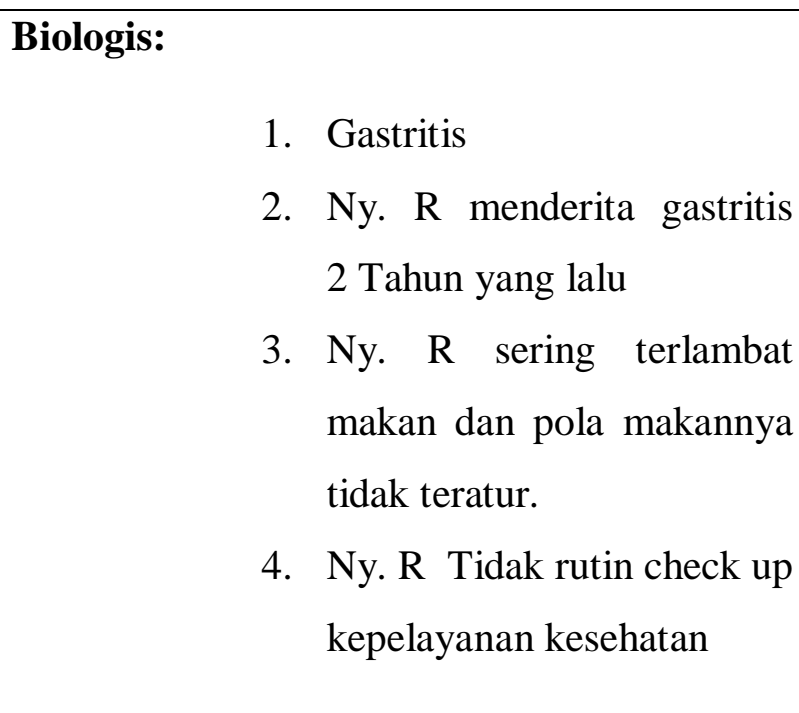 & $\begin{array}{l}\text { - Kondisi } \\
\text { penyakitnya } \\
\text { sangat buruk } \\
\text {,setiap hari trus } \\
\text { mengeluh mual } \\
\text { dan muntah dan } \\
\text { tidak mau } \\
\text { makan alasan } \\
\text { tidak nafsu } \\
\text { makan. }\end{array}$ & Internal & $\begin{array}{l}\text { Sejak } 2 \text { tahun } \\
\text { yang lalu }\end{array}$ & - Gastritis \\
\hline $\begin{array}{l}\text { Psikologis : } \\
\text { 1. Ny. R memiliki kepribadian yang } \\
\text { Terbuka sebelumnya } \\
\text { 2. Ny. R merasa serba salah karena ketika } \\
\text { makan juga salah dan ketika tidak } \\
\text { makan juga sakit. }\end{array}$ & $\begin{array}{l}\text { Takut, gelisah, } \\
\text { dan putus asa } \\
\text { bagaimana jika } \\
\text { penyakit ini } \\
\text { tidak sembuh. } \\
\text { - Sering kepikiran } \\
\text { penyakitnya. }\end{array}$ & Internal & $\begin{array}{l}\text { Sejak } 1 \text { bulan } \\
\text { yang lalu }\end{array}$ & $\begin{array}{l}\text { - Cemas, takut, khawatir, } \\
\text { gelisah }\end{array}$ \\
\hline
\end{tabular}




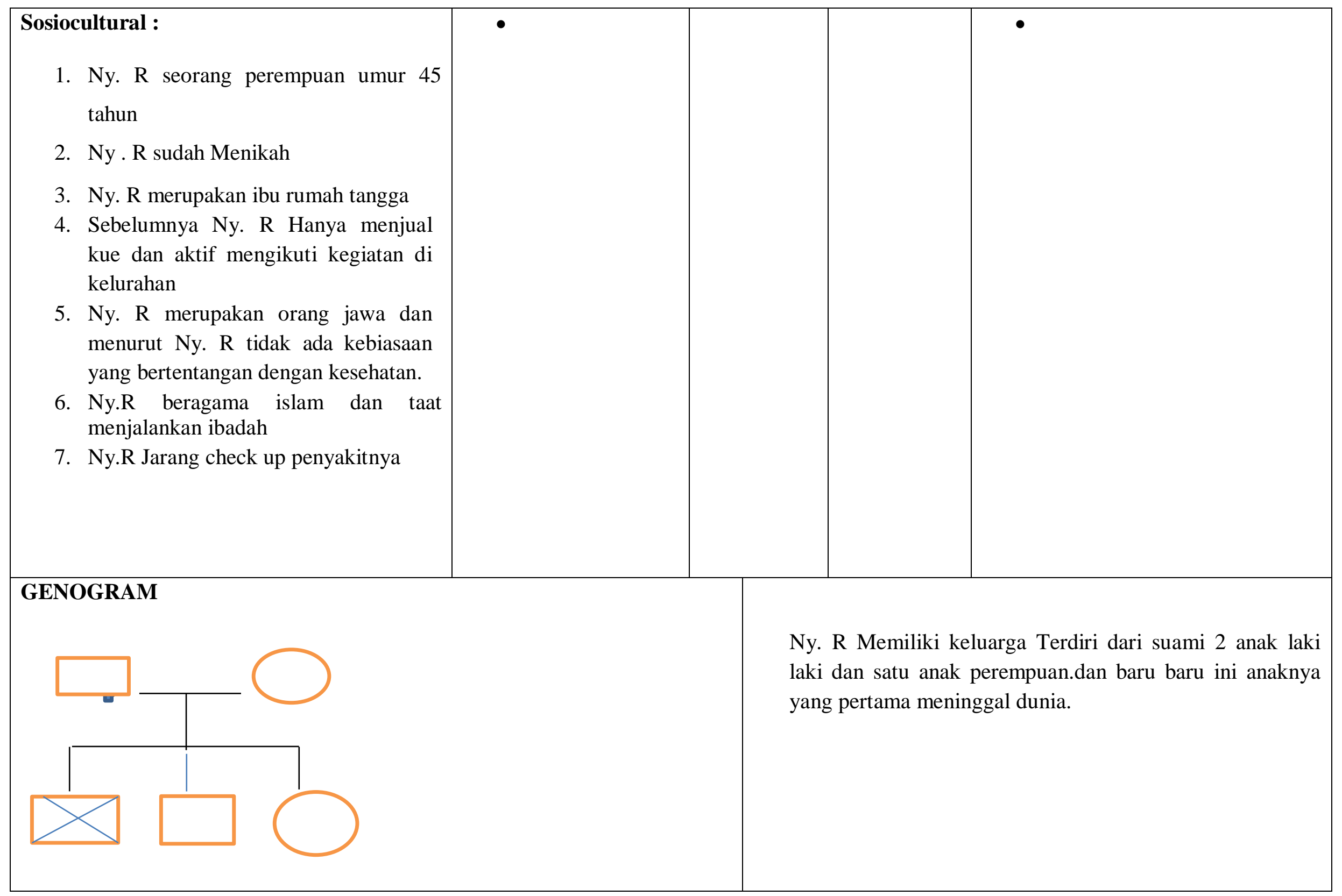




\subsubsection{PENILAIAN (RESPON)TERHADAP STRESSOR}

\begin{tabular}{|c|c|c|c|c|c|c|}
\hline STRESSOR & KOGNITIF & AFEKTIF & FISIOLOGIS & PERILAKU & SOSIAL & $\begin{array}{l}\text { DIAGNOSA } \\
\text { KEPERAWAT } \\
\text { AN }\end{array}$ \\
\hline $\begin{array}{l}\text { BIOLOGIS } \\
\text { - Gastritis }\end{array}$ & $\begin{array}{l}\text { - Menurut Ny. R } \\
\text { dia menderita } \\
\text { penyakit ini } \\
\text { dikarenakan } \\
\text { sering } \\
\text { terlambat } \\
\text { makan dan } \\
\text { juga } \\
\text { disebabkan } \\
\text { stress } \\
\text { berlebihan. } \\
\text { - Menganggap } \\
\text { penyakit } \\
\text { yang diderita } \\
\text { tidak akan } \\
\text { bisa sembuh } \\
\text { Tidak tahu apa } \\
\text { yang harus } \\
\text { dilakukan } \\
\text { untuk } \\
\text { penyakitnya } \\
\text { ini dia merasa } \\
\text { tidak akan } \\
\text { sembuh dan } \\
\text { tidak ada obat }\end{array}$ & $\begin{array}{l}\text { - Ny. R } \\
\text { merasa sedih } \\
\text { dan bingung } \\
\text { dengan } \\
\text { kondisi } \\
\text { penyakitnya } \\
\text { dan kerap } \\
\text { kali } \\
\text { menangis } \\
\text { Mengingat } \\
\text { mendiang } \\
\text { anaknya. }\end{array}$ & $\begin{array}{l}\text { - } \text { Sulit tidur } \\
\text { - Tidak nafsu } \\
\text { makan } \\
\text { - Ny. R tampak } \\
\text { lemas } \\
\text { - Pemeriksaan } \\
\text { TTV } \\
\text { TD: } 110 / 80 \\
\text { Mmhg }\end{array}$ & $\begin{array}{l}\text { - Ny. R } \\
\text { Tidak rutin } \\
\text { ke rumah } \\
\text { sakit } \\
\text { - Ekspresi } \\
\text { muka lesu } \\
\text {,lemas } \\
\text { - Ny.E tampak } \\
\text { diam dan } \\
\text { kadang ingin } \\
\text { menangis }\end{array}$ & $\begin{array}{l}\text { - Pasien } \\
\text { mendatangi } \\
\text { dan } \\
\text { menggunakan } \\
\text { fasilitas } \\
\text { kesehatan } \\
\text { apabila sudah } \\
\text { parah sekali } \\
\text { penyakitnya } \\
\text { untuk mencari } \\
\text { kesembuhan } \\
\text { terhadap } \\
\text { masalah yang } \\
\text { dihadapi saat } \\
\text { ini. }\end{array}$ & - Ansietas \\
\hline
\end{tabular}




\begin{tabular}{|c|c|c|c|c|c|c|}
\hline & yang pas. & & & & & \\
\hline $\begin{array}{l}\text { PSIKOLOGIS } \\
\\
\text { - sedih, cemas, } \\
\text { kesal dan } \\
\text { Bingung } \\
\text { dengan kondisi } \\
\text { penyakitnya } \\
\text { dan terlihat } \\
\text { tidak begitu } \\
\text { peduli karena } \\
\text { jarang mau di } \\
\text { ajak untuk } \\
\text { berobat. }\end{array}$ & $\begin{array}{l}\text { - Ny. R tahu } \\
\text { bahwa } \\
\text { Wajahnya } \\
\text { menurun dan } \\
\text { tidak bias di } \\
\text { gerakan } \\
\text { - Ny. R } \\
\text { mengaku } \\
\text { Sangat sedih } \\
\text { dan tidak } \\
\text { ingin bertemu } \\
\text { dengan } \\
\text { siapapun } \\
\text { Semenjak } \\
\text { kepergian } \\
\text { anaknya. }\end{array}$ & $\begin{array}{l}\text { - Merasa kesal } \\
\text { dan putus asa } \\
\text { dengan } \\
\text { penyakitnya } \\
\text { yang semakin } \\
\text { lama semakin } \\
\text { parah. }\end{array}$ & $\begin{array}{l}\text { - } \text { Pusing } \\
\text { - } \text { Nyeri } \\
\text { - Sakit di bagian } \\
\text { ulu hati } \\
\text { - Sering mual dan } \\
\text { muntah } \\
\text { - Sulit tidur dan } \\
\text { sering } \\
\text { terbangun } \\
\text { apabila tidur } \\
\text { - Kepala dan } \\
\text { belakang } \\
\text { telinga terasa } \\
\text { sakit. } \\
\text { - Tidak nafsu } \\
\text { makan } \\
\text { - Ny. R tampak } \\
\text { lemas } \\
\text { - Wajah Ny. R } \\
\text { tampak tidak } \\
\text { simetris dan } \\
\text { turun. } \\
\text { - Wajah Ny. R } \\
\text { tampak pucat. } \\
\text { - Pemeriksaan } \\
\text { TTV } \\
\text { TD: } 110 / 80 \\
\text { mmhg } \\
\mathrm{N}: 88 \times \text { / menit } \\
\text { P : } 20 \mathrm{x} / \mathrm{menit}\end{array}$ & $\begin{array}{ll}\text { - } & \text { Tampak } \\
\text { cemas dan } \\
\text { tidak } \\
\text { tenang } \\
\text { - } \text { Kadang Ny. } \\
\mathrm{R} \mathrm{tampak} \\
\text { murung } \\
\text { - } \mathrm{Ny.} \quad \mathrm{R} \\
\text { tampak } \\
\text { gelisah } \\
\text { - Ny. } \\
\text { tampak } \\
\text { aktif dalam } \\
\text { menerima } \\
\text { perawatan } \\
\text { Ny. } \\
\text { menunduk } \\
\text { saat bercerita } \\
\text { dan jarang ada } \\
\text { kontak mata. }\end{array}$ & $\begin{array}{l}\text { - Hubungan Ny. } \\
\mathrm{R} \text { dengan } \\
\text { keluarga baik } \\
\text { - Ny. R kurang } \\
\text { bersosialisasi } \\
\text { dengan } \\
\text { keluarga } \\
\text { Ny. R tetap } \\
\text { mengikuti } \\
\text { program } \\
\text { pengobatan } \\
\text { yang } \\
\text { diberikan } \\
\text { kepadanya } \\
\text { akan tetapi } \\
\text { tidak begitu } \\
\text { antusias dan } \\
\text { Ny. R dalam } \\
\text { menerima } \\
\text { perawatan }\end{array}$ & - Kehilangan \\
\hline
\end{tabular}




\begin{tabular}{|c|c|c|c|c|c|c|}
\hline & & & $\mathrm{S}: 36^{0} \mathrm{C}$ & & & \\
\hline $\begin{array}{l}\text { sering } \\
\text { Memikirkan } \\
\text { Apakah } \\
\text { penyakitnya } \\
\text { bisa sembuh } \\
\text { dan sangat } \\
\text { sedih karena } \\
\text { setiap jumpa } \\
\text { keluarga pasti } \\
\text { bertanya } \\
\text { kenapa bisa } \\
\text { terserang } \\
\text { penyakit itu } \\
\text { dan membuat } \\
\text { sangat malu } \\
\text { dan terkadang } \\
\text { putus asa } \\
\text { sekali. }\end{array}$ & $\begin{array}{l}\text { - Ny. R merasa } \\
\text { tidak berdaya } \\
\text { dengan } \\
\text { keadaannya } \\
\text { - Ny. R berfikir } \\
\text { ia selalu } \\
\text { merepotkan } \\
\text { kluarga } \\
\text { karena biaya } \\
\text { pengobatan } \\
\text { yang begitu } \\
\text { banyak. } \\
\text { - Keluarganya } \\
\text { juga panik bila } \\
\text { terlalu lama } \\
\text { dalam keadaan } \\
\text { seperti ini } \\
\text { merasa } \\
\text { Kasihan } \\
\text { Kepada } \\
\text { keluarga } \\
\text { yang harus } \\
\text { menangani } \\
\text { biaya terapi }\end{array}$ & $\begin{array}{l}\text { - Merasa } \\
\text { khawatir dan } \\
\text { sedih kepada } \\
\text { dirinya } \\
\text { sendiri. } \\
\text { - Merasa } \\
\text { bersalah } \\
\text { karena } \\
\text { merasa } \\
\text { merepotkan } \\
\text { keluarga } \\
\text { - Merasa } \\
\text { bosan } \\
\text { dengan } \\
\text { keadaan } \\
\text { sekarang } \\
\text { yang tidak } \\
\text { kunjung } \\
\text { membaik. }\end{array}$ & $\begin{array}{l}\text { - } \text { Pusing } \\
\text { - } \text { bibir tampak } \\
\text { kering } \\
\text { - mata cekung } \\
\text { - Sulit tidur } \\
\text { - kepala terasa } \\
\text { tegang } \\
\text { - Tidak nafsu } \\
\text { Makan Serta } \\
\text { mual } \\
\text { muntah } \\
\text { - Ny.R tampak } \\
\text { lemas } \\
\text { - Wajah Ny.R } \\
\text { tampak pucat } \\
\text { Seperti } \\
\text { kekurangan } \\
\text { darah. }\end{array}$ & $\begin{array}{l}\text { - Kontak mata } \\
\text { ada tapi tidak } \\
\text { bertahan } \\
\text { lama dan } \\
\text { sering } \\
\text { menunduk } \\
\text { - Volume } \\
\text { suara } \\
\text { mengecil } \\
\text { - Sering } \\
\text { menangis } \\
\text { - Ny.R } \\
\text { tampak } \\
\text { gelisah Dan } \\
\text { khawatir. }\end{array}$ & $\begin{array}{l}\text { - Hubungan } \\
\text { Ny.R dengan } \\
\text { keluarga baik } \\
\text { - Hubungan } \\
\text { Ny. R dengan } \\
\text { petugas } \\
\text { kesehatan } \\
\text { baik } \\
\text { - Ny. R tidak } \\
\text { mengikuti } \\
\text { program } \\
\text { pengobatan } \\
\text { Dan terus } \\
\text { menjalani } \\
\text { terapi. }\end{array}$ & - Keputusasaan \\
\hline
\end{tabular}




\subsubsection{SUMBER KOPING}

\begin{tabular}{|c|c|c|c|c|c|}
\hline $\begin{array}{l}\text { Dianosa } \\
\text { Keperawatan }\end{array}$ & $\begin{array}{l}\text { Personal } \\
\text { Ability }\end{array}$ & Sosial Upport & Material Assets & Positie Belief & Terapi \\
\hline Ansietas & $\begin{array}{l}\text { Ny. R mampu } \\
\text { mengungkapka } \\
n \quad \text { perasaan } \\
\text { cemas }\end{array}$ & $\begin{array}{l}\text { Ny. R } \\
\text { mendapatkan } \\
\text { dukungan dar } \\
\text { keluarga untuk } \\
\text { kesembuhannya } \\
\text { terutama dari } \\
\text { suaminya }\end{array}$ & $\begin{array}{l}\text { - } \text { Ekonomi Ny. } \\
\text { R menengah } \\
\text { - } \text { pengobatan } \\
\text { ditanggung BPJS } \\
\text { - Jarak rumah Ny. R } \\
\text { dengan tempat } \\
\text { pelayanan } \\
\text { kesehatan } \pm 4 \mathrm{KM}\end{array}$ & $\begin{array}{l}\text { - } \text { Ny.R percaya bahwa } \\
\text { petugas kesehatan akan } \\
\text { membantunya } \\
\text { - Ny.R berharap cepat } \\
\text { sembuh agar tidak } \\
\text { merepotkan }\end{array}$ & $\begin{array}{l}\text { Terapi Generalisasi : } \\
\text { 1) SP 1-4 Kecemasan } \\
\text { untuk individu } \\
\text { Terapi spesialis: } \\
\text { - Relaksasi progresif: } \\
\text { - Behavior Theraphy } \\
\text { - Psikoedukasi } \\
\text { keluarga }\end{array}$ \\
\hline
\end{tabular}




\begin{tabular}{|c|c|c|c|c|c|}
\hline & $\begin{array}{l}\text { Mampu } \\
\text { sebagai } \\
\text { pengganti } \\
\text { akibat kondisi } \\
\text { yang berubah }\end{array}$ & & & & \\
\hline
\end{tabular}




\subsubsection{MEKANISME KOPING}

\begin{tabular}{|c|c|}
\hline HAL YANG DILAKUKAN & ANALISA \\
\hline $\begin{array}{l}\text { - Ny R mengatakan bila ada masalah, maka } \\
\text { Suaminya akan membicarakan dengan dan } \\
\text { keluarga untuk mencari jalan keluarnya } \\
\text { - Bila sakit Ny R berobat ke pelayanan } \\
\text { kesehatan } \\
\text { - Ny R taat menjalankan ibadah sesuai } \\
\text { dengan keyakinannya } \\
\text { - Ny R selalu berdoa kepada Allah SWT } \\
\text { untuk kesembuhannya. }\end{array}$ & 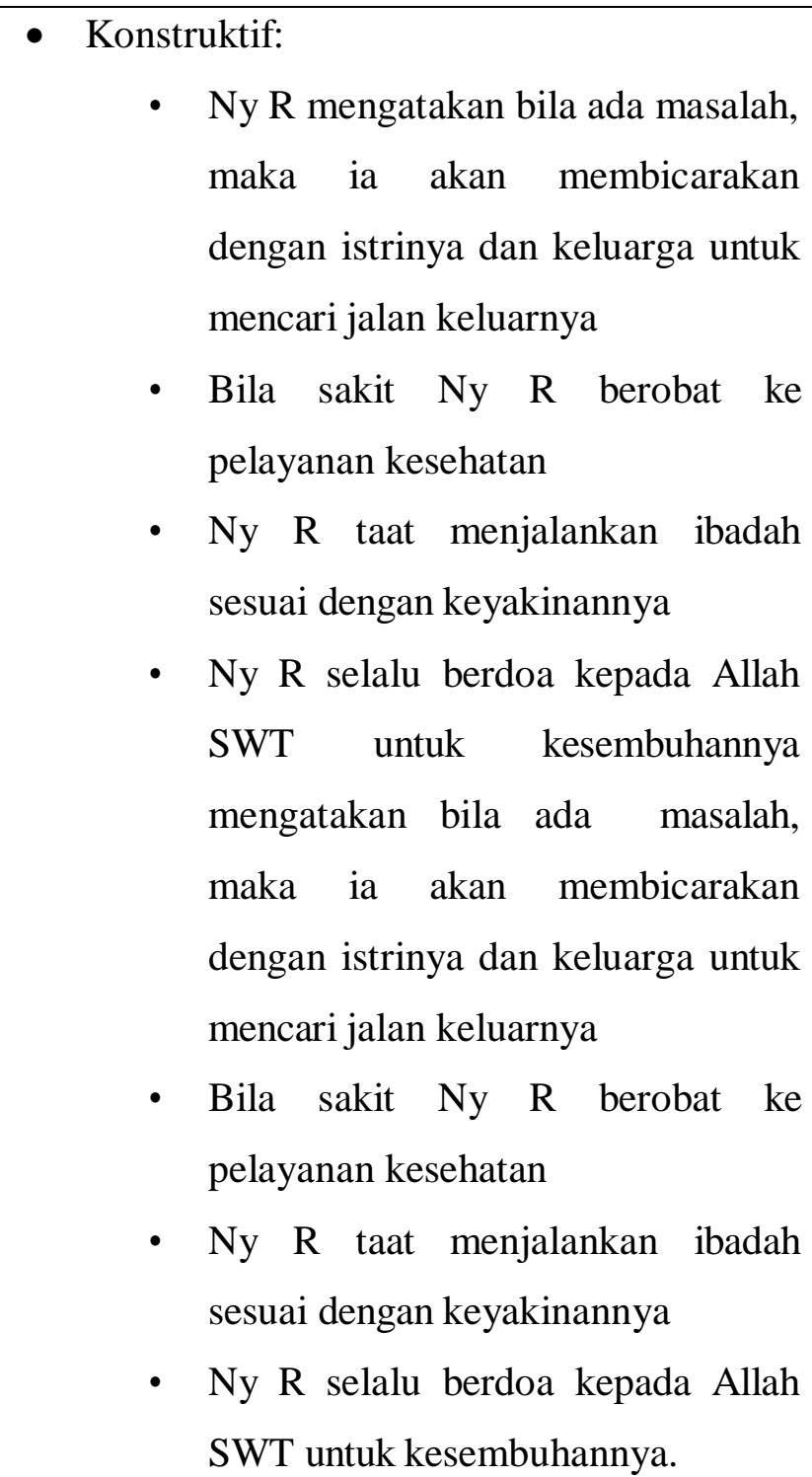 \\
\hline
\end{tabular}




\subsubsection{STATUS MENTAL}

\begin{tabular}{|l|l|}
\hline 1. Penampilan & $\begin{array}{l}\text { Bersih, Rapi, Tidak tercium bau, Ny R tampak gelisah dan } \\
\text { murung. }\end{array}$ \\
\hline 2. Pembicaraan & Berbicara dengan jelas tapi pelan. \\
\hline 3. Aktifitas motoric & Saat di wawancara pasien tampak gelisah \\
\hline 4. Interaksi selama wawancara & Cukup kooperatif \\
\hline 5. Alam perasaan & Ny R menunjukkan ekspresi takut dan khawatir \\
\hline 6. Afek & Sesuai dengan stimulus yang diberikan \\
\hline 7. Presepsi & Ny R tidak mengalami ganguan presepsi dan sensori \\
\hline 8. Isi piker & Masih bisa di ajak ngobrol tentang banyak kenangan \\
\hline 9. Proses piker & Cukup Baik \\
\hline 10. Tingkat kesadaran & Compos mentis (Normal) \\
\hline 11. Daya ingat & Ny R tidak mengingat beberapa kejadian dalam hidupnya \\
\hline 12. Kemampuan berhitung & Kemampuan berhitung cukup baik \\
\hline 13. Penilaian & $\begin{array}{l}\text { Ny R belum mampu menyebutkan bagaimana Ny R lekas } \\
\text { sembuh. }\end{array}$ \\
\hline 14. Daya tilik diri & $\begin{array}{l}\text { Ny R menyadari bahwa saat ini ia sedang sakit, Ny R } \\
\text { hanya bisa berdoa supaya lekas Ny R menyadari ia } \\
\text { memiliki istri, anak-anak dan keluarga yang } \\
\text { menyayanginya dan mendukung kesembuhannya }\end{array}$ \\
\hline
\end{tabular}

Kesimpulan : Mental Status Examination (MSE) tidak ada masalah gangguan jiwa, gangguan

Ny R lebih kepada Gangguan Mental Emosional (GME/Psikososial) 


\subsection{DIAGNOSA DAN TERAPI}

\section{DIAGNOSA KEPERAWATAN DAN TERAPI KEPERAWATAN \\ Ansietas \\ Sp1: mendiskusikan \\ penyebab,terjadinya prosesterjadi, tanda gejala,akibat \\ Sp2 :melatih teknik releksasi fisik Sp3:melatih mengatasi ansietas dengan distraksi dan hipnotis lima jari \\ Terapi Spesialis: TS, PMR, Logo ACT}

\section{Kehilangan}

Terapi perilaku kognitif

Terapi keluarga

\section{Keputusasaan}

SP 1

1. Bantu pasien mengenal keputusasaan: a. bantu klien untuk mengidentifikasi dan menguraikan perasaan sedih/kesendirian/ keputusasaannya) b. bantu klien mengenal penyebab putus asa

c. Diskusikan perbedaan antara perasaan dan pikiran klien terhadap kondisinya dengan kondisi real kondisi klien

d. bantu klien menyadari akibat putus asa

e. Dukung klien untuk mengungkapkan pengalaman yang mendukung pikiran, perasaan dan perilaku positif

2. Latih restrukturisasi pikiran melalui latihan berpikir positif dengan mengidentifikasi harapan dan penemuan makna hidup 


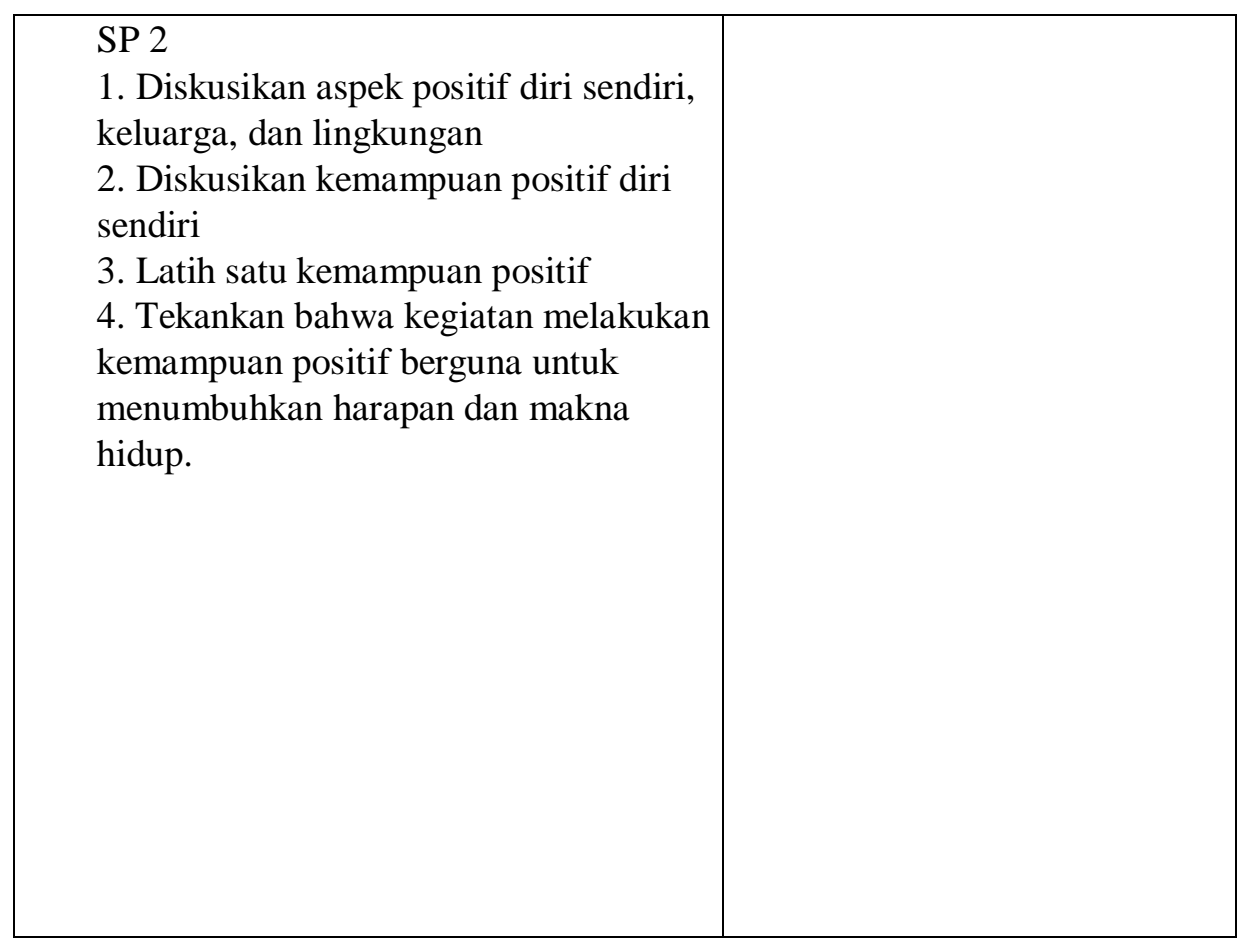





\subsection{IMPLEMENTASI TINDAKAN KEPERAWATAN DAN EVALUASI}

\begin{tabular}{|c|c|}
\hline $\begin{array}{l}\text { IMPLEMENTASI TINDAKAN } \\
\text { KPERAWATAN }\end{array}$ & EVALUASI \\
\hline $\begin{array}{l}\text { Tanggal : } 13 \text { November } 2021 \\
\text { Jam : } 09.00 \text { wib } \\
\text { 1. Menenangkan pasien } \\
\text { 2. Memahami keadaan pasien } \\
\text { 3. Mendiskusikan } \\
\text { penyebab,terjadinya proses terjadi, } \\
\text { tanda gejala,akibat dari ansietas } \\
\text { 4. Latihan cara mengatasi } \\
\text { kecemasan : } \\
\text { - Teknik relaksasi nafas dalam } \\
\text { - Distraksi dengan bercakap- cakap } \\
\text { hal positif } \\
\text { - Hipnotis } 5 \text { jari focus pada hal } \\
\text { yang positif } \\
\text { 5. Bantu Klien melakukan } \\
\text { nyylatihan sesuai dengan jadwal } \\
\text { kegiatan. }\end{array}$ & 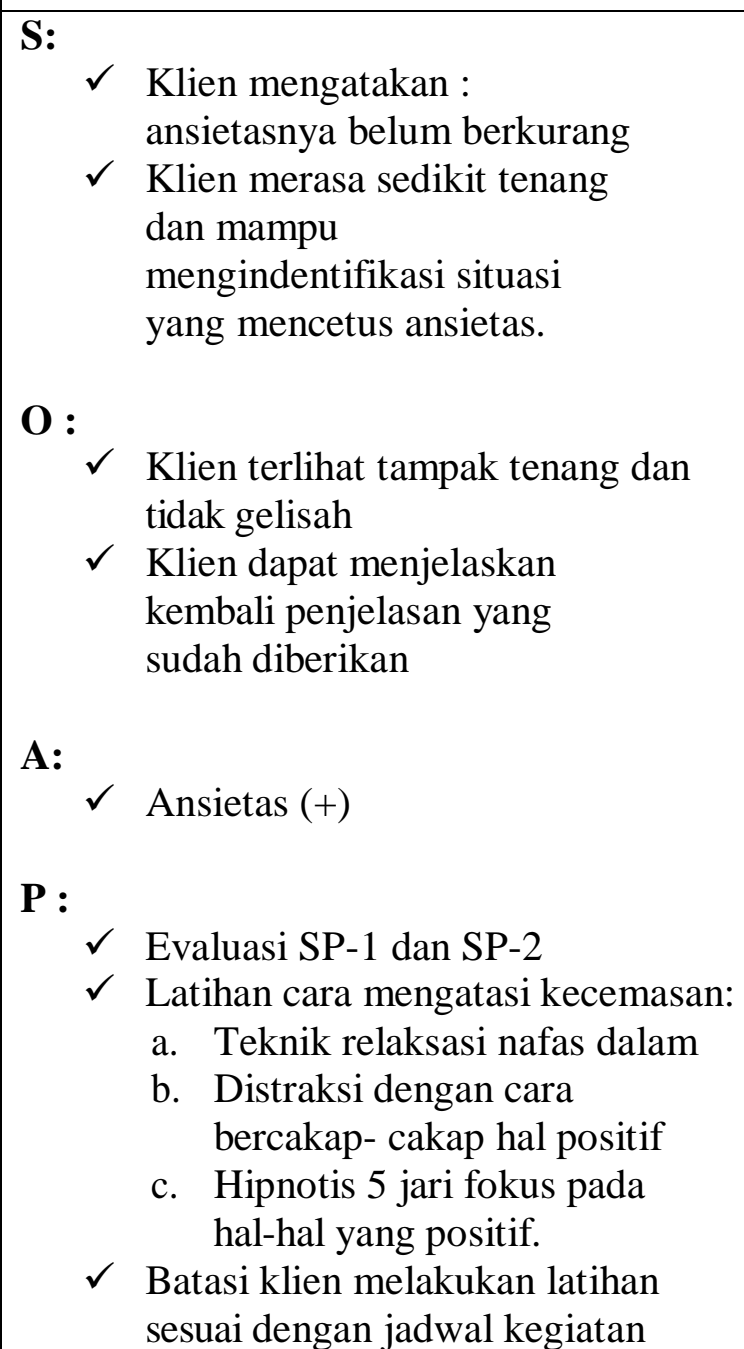 \\
\hline
\end{tabular}


Tanggal : 14 November 2021

Jam : $09.00 \mathrm{Wib}$

1. Latihan cara mengatasi kecemasan :

a. Teknik relaksasi nafas dalam

b. Distraksi bercakap-cakap dengan hal yang positif.

c. Hipnotis 5 jari fokus pada hal yang positif.

2. Bantu klien melakukan latihan sesuai dengan jadwal kegiatan.
S:

$\checkmark \quad$ Klien mengatakan yang di rasakan lebih tenang dan tidak merasa cemas

$\checkmark$ Klien mampu mengidentifikasikan situasi yang mencetus Cemas

$\checkmark$ Klien mengatakan sudah melakukan teknik tarik nafas dalam

$\checkmark \quad$ Klien mengatakan mampu melakukan teknik distraksi.

$\checkmark$ Klien mengatakan sudah mampu melakukan teknik hipnotis lima jari

O :

$\checkmark$ Klien terlihat tampak tenang dan tidak gelisah 


\begin{tabular}{|c|c|}
\hline & $\begin{array}{lll} & \checkmark & \text { Klien mampu menjelaskan kembali } \\
& \text { penjelasan yang sudah diberikan. } \\
& \checkmark & \text { Klien mampu menjelaskan teknik nafas } \\
& \text { dalam } \\
\checkmark & \text { Klien mampu melakukan distraksi. } \\
& \checkmark & \text { Klien mampu melakukan hipnotis lima } \\
& \text { jari. } \\
& \\
\text { A: } & & \\
& \checkmark & \text { Aietas }(+) \\
& & \\
\text { P : } & & \\
& \checkmark & \text { Bantu klien melakukan latihan sesuai } \\
& & \text { dengan jadwal kegiatan. } \\
\checkmark & \text { Terapi perilaku. } \\
\checkmark & \text { Terapi Kognitif. } \\
\checkmark & \text { Berikan pendidikan kesehatan. }\end{array}$ \\
\hline $\begin{array}{l}\text { Tanggal : } 15 \text { November } 2021 \\
\text { Jam : } 09.00 \mathrm{Wib} \\
\text { 3. Latihan cara } \\
\text { mengatasi kecemasan : } \\
\text { a. Teknik relaksasi nafas } \\
\text { dalam } \\
\text { b. Distraksi bercakap-cakap } \\
\text { dengan hal yang positif. } \\
\text { c. Hipnotis 5 jari fokus pada } \\
\text { hal yang positif. } \\
\text { 4. } \\
\text { Bantu klien melakukan } \\
\text { latihan sesuai dengan jadwal } \\
\text { kegiatan. }\end{array}$ & \begin{tabular}{|cl} 
S: & \\
$\checkmark$ & Klien mengatakan cemas yang di \\
& rasakan lebih tenang dan tidak \\
& merasa cemas lagi. \\
$\checkmark$ & Klien mampu mengidentifikasikan \\
& situasi yang mencetus Cemas \\
$\checkmark$ & Klien mengatakan sudah melakukan \\
& teknik tarik nafas dalam \\
$\checkmark$ & Klien mengatakan mampu \\
& melakukan teknik distraksi. \\
$\checkmark$ & Klien mengatakan sudah mampu \\
& melakukan teknik hipnotis lima jari \\
$\mathrm{O}$ & \\
$\checkmark$ & Klien terlihat tampak tenang dan tidak \\
& gelisah \\
A & Ansietas (-) \\
P : & Bantu klien melakukan latihan sesuai \\
jadwal kegiatan. & \\
& $\checkmark$ Berikan pendidikan kesehatan
\end{tabular} \\
\hline
\end{tabular}




\section{BAB 4 \\ PEMBAHASAN}

Setelah penulis melaksanakan asuhan keperawatan kepada $\mathrm{Ny} R$ dengan Kecemasan di Gg. Mesjid No 7 maka penulis akan membahas kesenjangan antara teoritis dengan tinjauan kasus. Pembahasan dimulai melalui tahapan proses keperawatan yaitu pengkajian, diagnosa keperawatan, perencanaan, pelaksanaan dan evaluasi.

\subsection{Pengkajian}

Selama pengkajian dilakukan pengumpulan data dari beberapa sumber, yaitu dari pasien dan tetangga sekitar. Maka penulis melakukan pendekatan kepada pasien melalui komunikasi teraupetik yang lebih terbuka membantu klien untuk memecahkan perasaannya dan juga melakukan observasi kepada pasien. Adapun upaya tersebut yaitu :

1. Melakukan pendekatan dan membina hubungan saling percaya diri pada klien agar klien lebih terbuka dan lebih percaya dengan menggunakan perasaan.

2. Mengadakan pengkajian klien dengan wawancara. Dalam pengkajian ini, penulis tidak menemukan kesenjangan karena ditemukan hal sama seperti: diteori: Kecemasan adalah keadaan emosi dan pengalaman subyektif individu, tanpa objek yang spesifik karena ketidaktahuan dan mendahului pengalamanya yang baru seperti penyakitnya saat ini

\subsection{Tahap perencanaan}

Perencanaan dalam proses keperawatan lebih dikenal dengan rencana asuhan keperawatan yang merupakan tahap selanjutnya setelah pangkajian dan penentuan diagnosa keperawatan. Pada tahap perencanaan penulis hanya menyusun rencana tindakan keperawatan sesuai dengan pohon masalah keperawatan yaitu: Kecemasan. Pada tahap ini antara tinjauan teoritis dan tinjauan kasus tidak ada kesenjangan sehingga penulis dapat melaksanakan 
tindakan seoptimal mungkin dan didukung dengan seringnya bimbingan dengan pembimbing.

Secara teoritis digunakan cara strategi pertemuan sesuai dengan diagnosa keperawatan yang muncul saat pengkajian. Adapun upaya yang dilakukan penulis yaitu :

1. Individu mengatakan ketidakpastian tentang fluktuasi tingkat energi dan bersikap

2. Individu menunjukan sikap apatis terhadap perburukan fisik yang terjadi dengan mengabaikan kepatuhan pasien terhadap program pengobatan. 


\subsection{Tahap Implementasi}

Pada tahap implementasi, penulis hanya mengatasi 1 masalah keperawatan yakni: diagnosa keperawatan Kecemasan merupakan keadaan emosi dan pengalaman subyektif induvidu,tanpa objek spesifik karena ketidaktahuan dan mendahului semua pengalaman yang di alami penyakit Hipertensi

\subsection{Tahap Evaluasi}

Pada tinjauan teoritis evaluasi yang diharapkan adalah :

a. Membina hubungan saling percaya

b. Mengenali dan mengekspresikan emosinya

c. Mampu mengenal ansietas

d. Mampu mengatasi ansietas melalui teknik releksasi

e. Mampu mengatasi ansietas dengan distraksi

f. Mampu mengatasi ansietas melalui hipnotis lima jari

g. Mampu mengatasi ansietas melalui kegiatan 


\section{BAB 5}

PENUTUP

\subsection{Kesimpulan}

Berdasarkan uraian pada pembahasan diatas, maka penulis dapat disimpulkan bahwa:

1. Pengkajian dilakukan secara langsung pada klien dan juga dengan menjadikan status klien sebagai sumber informasi yang dapat mendukung data-data pengkajian. Selama proses pengkajian, perawat mengunakan komunikasi terapeutik serta membina hubungan saling percaya antara perawat-klien. Pada kasus Jarang membersihkan Kecemasan: Gastritis

2. Diagnosa keperawatan yang utama pada klien dengan Kecemasan: Gastritis

3. Perencanaan dan implementasi keperawatan disesuaikan dengan strategi pertemuan pada pasien.

4. Evaluasi keperawatan yang dilakukan menggunakan metode subyektif,obyektif,assessment dan planing.

\subsection{Saran}

1. Untuk institusi pendidikan

Penulis mengharapkan lebih meningkatkan pelayanan pendidikan yang lebih tinggi dan menghasilkan tenaga kesehatan yang profesional berwawasan global

2. Untuk keluarga

Penulis mengharapkan agar individu dan keluarga bisa mengerti tentang penyakit Gastritis, dan meningkatkan perilaku hidup sehat dengan tujuan meningkatkan kualitas hidup. 


\section{DAFTAR PUSTAKA}

1. Hulu, E. K., \& Pardede, J. A. (2016). Dukungan Keluarga Dengan Tingkat Kecemasan Pasien Pre Operatif Di Rumah Sakit Sari Mutiara Medan. Jurnal Keperawatan, 2(1), 12.

2. Marbun, A., Pardede, J. A., \& Perkasa, S. I. (2019). Efektivitas Terapi Hipnotis Lima Jari terhadap Kecemasan Ibu Pre Partum di Klinik Chelsea Husada Tanjung Beringin Kabupaten Serdang Bedagai. Jurnal Keperawatan Priority, 2(2), 92-99. https://doi.org/10.34012/jukep.v2i2.568

3. Pardede, J. A. (2020). Standar Asuhan Keperawatan Jiwa Dengan Masalah Kecemasan. Jurnal Ilmu Kesehatan

4. Pardede, J. A., Simanjuntak, G. V., \& Laia, R. (2020). The Symptoms of Risk of Violence Behavior Decline after Given Prgressive Muscle Relaxation Therapy on Schizophrenia Patients. Jurnal Ilmu Keperawatan Jiwa, 3(2), 91-100.

5. Pardede, J. A., Sitepu, S. F. A., \& Saragih, M. (2018). Pengaruh Teknik Relaksasi Nafas Dalam dengan Terapi Hipnotis Lima Jari Terhadap Kecemasan Pre Operatif. Jurnal Kesehatan Jiwa, 1(10).

6. Pardede, J. A., Keliat, B. A., Damanik, R. K., \& Gulo, A. R. B. (2020). Optimalization of Coping Nurses to Overcoming Anxiety in the Pandemic of Covid-19 in Era New Normal. Jurnal Peduli Masyarakat, 2(3), 105-112.

7. Pardede, J. A., Sinaga, T. R., \& Sinuhaji, N. (2021). Dukungan Keluarga Dengan Tingkat Stres Narapidana Di Lembaga Pemasyarakatan. Window of Health: Jurnal Kesehatan, 98-108.

8. Hartati, S., \& Cahyaningsih, E. (2013). Hubungan Perilaku Makan Dengan Kejadian Gastritis Pada Mahasiswa AKPER Manggala Husada Jakarta Tahun 2013. Jurnal Keperawatan, 6(1), 51. DOI: https://doi.org/10.22219/jk.v6i1.2852

9. Ilham, Muhammad Ishak., Haniarti., Usman. (2019). Hubungan Pola Konsumsi Kopi Terhadap Kejadian Gastritis Pada Mahasiswa Muhammadiyah Parepare. Jurnal Ilmiah Manusia dan Kesehatan 2(3). https://doi.org/10.31850/makes.v2i3.189

10. Kusnadi, E. \& Yundari, D. T. (2020). Hubungan Stress Psikologis Dengan Kejadian Gatriris di Wilayah Kerja Puskesmas Cisurupan. Jurnal Medika Cendikia 7(1). : https://doi.org/10.33482/medika.v7i1.128 
11. Amin Huda, \& Hardi, K. (2015). Aplikasi Asuhan Keperawatan Berdasarkan Diagnosa Medis Dan Nanda Nic-Noc (2nd ed). Yogyakarta: Mediaction.

12. Tussakinah \& Burhan. (2018) Hubungan Pola Makan dan Tingkat Stres terhadap Kekambuhan Gastritis. Jurnal Kesehatan Andalas, Volume 7: 2

13. Tussakinah, Widiya., Masrul.,\& Ida Rahman Burhan. (2018). Hubungan Pola Makan dan Tingkat Stress Terhadap Kekambuhan Gastritis di Wilayah Kerja Puskesmas Tarok Kota Payakumbuh Tahun 2017. Jurnal Kesehatan Andalas, 7(2).

: https://doi.org/10.25077/jka.v7i2.805

14. Verawati, L. (2020). Profil Demografi, Pengetahuan Dan Perilaku Pencegahan Gastritis Pada Mahasiswa Keperawatan Universitas Advent Indonesia. Jurnal Nutrix,4 (2), 2-3. Wahyudi, Ari., Farida, Halis.D.K., Mia Andinawati. (2018). 